\title{
The Effect of Bankruptcy Prediction Using Ohlson Score Model Towards Stock Returns (Study in Textile and Garment Company Listed in IDX For Year 2010-2014)
}

\author{
Ayu Putri Wulandari ${ }^{1}$ Norita $^{2}$, Aldilla Iradianty ${ }^{3}$
}

\begin{abstract}
The deceleration of Indonesian economics growth seen by the slowdown of GDP's growth has brought a lot of impact in various sector of Industry. One of them are manufacturing Industry, particulary in Textile and Garment industry. It can be seen from the decline of manufacturing company's growth which reached $-1,98 \%$ in the second quarter of 2015 , and also the decline of the textile products export trend, as well as a number of textile and garment companies which went bankrupt. Those condition which affect textile and garment companies are the symptomps of impending Financial Distress which is the beginning of Bankruptcy. Bankruptcy can be early predicted by various methods, one of them is Ohlson Score (1980). Besides bankruptcy prediction, another important thing which should be known is investor welfare, which is reflected from stock return. This is the main question of the research, that is how far could Ohlson Score influences stock return. The statistical analysis techniques used are panel data regression method, and Mann Whitney test. This study consists of 7 companies. The result shows that there is a negative influence between ohlson score towards stock return, but not significantly.
\end{abstract}

Keyword: Financial Distress, Bankruptcy, Ohlson Score, Stock Return

\section{Introduction}

The existence of the industry in a country can be affected by various factors, one of themis external environment , especially economic factors. Each year, Indonesia suffered economic events, which affect global and regional economic situation. According to the Central Bureau of Statistics [1], Indonesia has affected a situasion called economic deceleration. Indonesia's economic deceleration began to seen in 2014 that continues to touch the figure of the second quarter to $4.67 \%$. Beside those condition, other policy issues Indonesia experienced is the rising price of fuel oil (BBM). These condition and economic policies above have brought changes in conditions of various industrial sectors in Indonesia, one of them is the declining in manufacturing sector, particularly the Textile and Garment company. Economic deceleration also impact the export declining of textile products that fall to $1.09 \%$.

Other events can be highlighted in the textile and garment companies are delisting, Delisting is the issuer of the stock exchange. Delisting incident ever affected a Sector Textile and Garment company, as quoted in the Kontan Newspaper [2] on March 16, 2013 thatPanasia Filamen Inti Tbk (PAFI)delisted because it does not improve the financial performance and do not have a clear business plan.

Those events that affected textile and garment industry have abig potential for the occurrence of Financial Distress. According to Black's Law Dictionary in Rodoni and Ali [3] that the financal distress is the deterioration of the company's previous condition. The occurrence of Financial Distress in a company can be predicted by analyzing the company's financial statements. In addition to performing a simple ratio analysis, there are several models for mempredisikan Financial Distress of a company, including Altman Z-Score, Springate,
Zmijewski, and Ohlson Score. Compared with other methods, Ohlson method is a method that not only involve the financial ratio only, but involve elements of inflation, which is reflected in the formula Size, which is the logit of the total assets divided by GNP-price index level. This study also applies atrends straight line forecasting methods, with the smallest quadrant models. These decision made beacuse the Central Bureau of Statistics has not released any real GNP Indonesia in 2014

For public companies, the stock is a main source of corporate funding. The presence of the stock price may reflect a general picture of a company. Stock prices tend to fall in a relatively long period of time, can give an indication to investors that the company is in a poor and unhealthy condition. Conversely, if the stock price tends to rise, it will indicate the condition of the company is good and healthy. Besides considering the stock price, the main purpose of an investor to buy stocks is to gain some return, one of which is in the form of stock returns.

Return is the main investor's motivation and consideration in selecting a stock, maximizing investor return is the main goal in investing. Tandelilin [4] reveals the sources of return consists of two main components, namely yield and capital gain (loss).This study emphasizes on several things,those are the corporate bankruptcy prediction using Ohlson Score models, The Influence between Ohlson Score towards stock returns, and the difference between stock return in failed and non failed company.

\section{Literature Survey}

\subsection{Financial Performace}

Evaluating company's financial performance is one of many tool to determine the quality of the company. By evaluating the financial performance, company will 


\section{International Journal of Science and Research (IJSR) \\ ISSN (Online): 2319-7064}

Index Copernicus Value (2013): 6.14 | Impact Factor (2014): 5.611

determine its deficiency, so it could be fixed as soon as possible.

Financial performance also has a close relation with the financial management, where its the one of financial management activity. Like Keown [5] describes "Financial management concerned with the maintenance and creation of economic value or wealth. Consequently, this course focuses on decision making with an eye toward creating wealth...."

One of the main sources about company's financial performance is by observing and analyzing financial statements. This was revealed by Keown, et al [5] "... by looking at the basic financial statements that are a primary source of information about a firm's financial performance"

\subsection{Financial Statement}

The company financial statements is a sheet that provides information on some of the company's business activities, including financing, investing, and operating activities. These statement reflectes by some statements about financial statement definition. There are several definitions of financial statement. One of them was stated by Titman [6] that A Firm's statements provide a visual representation of the firm that is used to describe the business to investors and other outside of the firm as well as to form employee". Another statement came form Kamaludin [7] whom states that "The financial statements are the final result of a recording process which is a summary of financial transaction that occured during the financial year concerned"

According to Rodoni and Ali [3], the financial statements is a report published by a compant for its shareholders. This report contains the basic of financial statements, and also the management's analysis about former operating activites, and opinion about company;s prospects for the future.

\subsection{Financial Statement Analysis}

According to Subramanyam and Wild [8] Financial statement analysis is the application of tools and analytical techniques for financial statement general purposes, and the related data which generate useful estimatation and conclusions in business analysis.

Subramanyam and Wild [8] explained that the analysis of financial statements are an integral important part of the wider business analysis. Described in the same book that analyzes the business (business analysis) is the process of evaluating the economic outlook and the risk of the company. It includes an analysis of the company's business environment., as well as the financial position and performance

\subsection{Financial Distress}

Financial distress is one of the company's condition which can be detected by the analysis of financial statements.
This company's condition can be a sign of impending a worse situation, which is bankruptcy. Companies should aware of the coming of financial distress, so that does not lead to a worse stage.

There are several definitions of financial distress, as described by Black Law's Dictionary in Rodoni and Ali [3] that the Financial distress is defined as an insolvency, the condition of assets or property and obligations of a person who was formerly available to be not enough to pay off the debt.

Tirapat and Nittayagasetawat (1999) in Rodoni and Ali [3] defines financial distress as the company which terminated its operations by the authority of the government and the company is required to carry out the restructuring plan.

\subsection{Bankruptcy}

Bankruptcy is one of many things that is avoided by any company. Knowing the bankruptcy possibility is one of the financial statement analysis's objective. By knowing the bankruptcy possibility, the company can make long-term plans, and anticipate to avoid the situation

Commonly, bankruptcy can occur because companies can not afford to pay the debt. As stated Gitman (1996) in Karamzadeh [9] that bankruptcy is a legal status that applies to the bankruptiest, the parties are not able to pay their debts to creditors. Commonly, bankruptcy decided by the courts many by the debtor, that is, when the amount of debt the company is higher than total assets.

Goudie (1987) in Karamzadeh [9] revealed there are some things that can lead to bankruptcy, such as mismanagement, economic events, the government's decision, as well as natural events and accidents.

\subsection{Ohlson Score}

Ohlson Score discovered by James Ohlson in 1980. In the early discoveries time, Ohlson dubious Multiple Discriminant Analysis (MDA) method founded by Altman (1968). As his equal, O-score using logistic regression in its calculations.According Ghozali [10] "Logistic regression is actually similar to discriminant analysis that we want to test whether the probability of occurrence of the dependent variable can be predicted by the independent variables". The formula of Ohlson Score is:

$$
\begin{aligned}
& \text { O-Score }=-1,32-0,407(\text { Size })+6,03\left(\frac{T L}{T A}\right)-1,43\left(\frac{W L}{T A}\right)+ \\
& 0,0757\left(\frac{C L}{C A}\right)-2,37\left(\frac{N I}{T A}\right)-1,83\left(\frac{F U}{T L}\right)+0,285(\text { INTWO) } \\
& -1,72\left(\text { OENEG) }-0,521\left[\frac{N I_{t}-N I_{t-1}}{\left|N I_{t}\right|+\left|N I_{t-1}\right|}\right](1)\right.
\end{aligned}
$$

\section{Description:}

a. $\quad$ Size $=\log ($ total assets/GNP price-level index $)$

b. $\quad$ TLTA $=$ Total liabilities/Total Asset

c. $\quad$ WCTA $=$ Working Capital/Total Assets

\section{Volume 4 Issue 12, December 2015}




\section{International Journal of Science and Research (IJSR) \\ ISSN (Online): 2319-7064}

Index Copernicus Value (2013): 6.14 | Impact Factor (2014): 5.611

d. $\quad$ CLCA $=$ Current Liabilities/Current assets

e. $\mathrm{OENEG}=$ One if total liabilities exceeds total assets, zero otherwise

f. $\quad$ NITA $=$ Net Income/Total Assets

g. $\quad$ FUTL $=$ Funds provided by operation divided by total liabilities

h. INTWO = One if net income was negative for the last two years, zero otherwise

i. $\quad \mathrm{CHIN}=\left(N I_{t}-N I_{t-1}\right) /\left(\left|N I_{t}\right|+\left|N I_{t-1}\right|\right)$

The result of Ohlson Score calculation above can be categorized by two, such as Failed and Non-Failed:

Table 1: Bankruptcy Probability's Criteria

\begin{tabular}{|c|c|}
\hline Probability or P(O-score) & Category \\
\hline O-Score $>0,038$ & Failed \\
\hline O-Score $<0,038$ & Non-Failed \\
\hline
\end{tabular}

Source: Ohlson [11]

\subsection{Investment}

Tandelilin [4] revealed that investment is a commitment of a number of funds or other resources were done at this time, with the purpose that to get some number of advantages in the future. An opinion about the definition of investment also disclosed by Relly and Brown (2009) in Fahmi [12] "Investment is the current commitment of dollars for a period of time to derive future payments that will compensate the investor for (1) the time the funds are commited. (2) the expected rate of inflation, (3) the uncertainty of the future payments. "

While Herlianto [13] stated that the investment is basically the placement of the funds at this time in order to gain some advantage in the future.

According Tandelilin [4] if it is associated with a variety of activities, types of investment can be divided into two, such as: Real Investment and Financial Investment.

\subsection{Stock Return}

Return in investment can be either a profit or a loss. According Tandelilin [4] There are two components of total return on investment. First, any cash received when it has investments. For shares, a cash payment from the company to the shareholders is called dividend. Second, the value of the assets purchased may change, which means that is a capital gain or capital loss. For stocks, the price can be increased so that the holder is said to derive capital gains or can also be decreased called a capital loss. Because the source of the return comes from dividends and capital gains / capital loss, the calculation of return can be started by calculating the dividend the company, and continued to calculate the capital gain or capital loss.

$$
\begin{aligned}
& \text { Dividen Yield }=\frac{D_{t}}{P_{t-1}}(2) \\
& \text { Capital Gains }=\frac{\left(P_{t}-P_{t-1}\right)^{\xi}}{P_{t-1}}(3)
\end{aligned}
$$

Description:
Dt: Dividend beginning of year $t$

Pt: The stock price per share at the end of the year $\mathrm{P}_{\mathrm{t}-1}$ : The stock price per share at the beginning of the year

\section{Problem Definiton}

Based on the background and theoritical framework, the problem definition in this research can be formulated as follows:

1. How does bankruptcy prediction using O-Score on the company Textile and Garment company listed in Indonesia Stock Exchange for year 2010-2014?

2. How is the movement of stock returns Textile and Garment company listed in Indonesia Stock Exchange in 2010-2014?

3. How is the condition of stock returns in company indicated failed?

4. How is the condition of stock returns in company indicated non failed?

5. Is there any stock returns's difference in company indicated failed and non failed?

6. How does the O-Score effect towards stock returns Textile and Garment company listed in Indonesia Stock Exchange in 2010-2014?

\section{Methodology or Approach}

This study uses quantitative methods, and the type is causal research. Type of scale used in this study is a ratio scale. According Sedarmayanti [14] The scale of numbers in a scalar ratio is the ratio of the absolute number at zero point. The population in this study are all textile and garment company listed on the Indonesia Stock Exchange until 2014. The total population is 18 companies. Populations are then selected by purposive sampling technique, and obtained 7 samples of the company, namely Polychem Indonesia Tbk, Argo Pantes Tbk, Apac Citra Tbk Centertex, Pan Brothers Tbk, Asia Pacific Fiber Tbk, Nusantara Inti Corpora Tbk, and Unitex Tbk. Authors obtain research data from the official website of Indonesia Stock Exchange (idx.co.id), and stock price history from Yahoo Finance official website.

To answer the problem definition, there are several tests and statistical analysis used. The first is descriptive analysis, to describe the condition of the stock return. Then proceed with the Kolmogorov-Smirnov test, which is a test for normality before continue to Mann Whitney Test. Next one is a different test Mann Whitney, the different test that can be done in the absence of normality. Then, regression panel data, regression model used in this research is panel data regression model. According Rosadi [15] Data panel is a combination of a time-cross (cross section) and time series data type, the number of observed variables or the number of categories and collected within a certain period. While the model used so-called panel data model. Before performing regression panel data, researchers conducted a test panel data model first, namely Test Chow / Likehood and Lagrange Multiplier Test. 


\section{International Journal of Science and Research (IJSR) \\ ISSN (Online): 2319-7064 \\ Index Copernicus Value (2013): 6.14 | Impact Factor (2014): 5.611}

\section{Result / Discussion}

\subsection{Banktuptcy Prediction}

Based on Ohlson Score calculation, showed that from overall 35 calculation, which consists of 7 companies and 5 period (2010-2014). 22, og those of that identified Failed, while 13 others identified Non failed. Polychem Indonesia Tbk has different conditions in every year. In 2010 these company identified Failed, but two subsequent period the condition of the company changed to Non Failed. In 2013 the condition of the company changes again to Failed, and ends with Non Failed in 2014. While the company Argo Pantes Tbk, Apac Citra Tbk Centertex, Unitex Tbk, and Asia Pasicif Fiber Tbk identified Failed for 5 consecutive years. Two others, namely Pan Brothers Tbk, and Nusantara Inti Corpora Tbk, identified Non Failed for 5 consecutive years.

\subsection{Descriptive Analysis of Stock Return}

Based on descriptive analysis between the Failed an Non Failed company. There are some differences between them. Such differences are outlined in Table 2:

Tabel 2: The Ohlson Score's Comparison in Failed and Non Failed Company

\begin{tabular}{|c|c|c|c|}
\hline \multicolumn{4}{|c|}{ Company's Category } \\
\hline \multicolumn{2}{|c|}{ Failed } & \multicolumn{2}{c|}{ Non Failed } \\
\hline Mean & 0,184136 & Mean & 1,099077 \\
\hline Median & 0,000000 & Median & 0,000000 \\
\hline Max & 2,309000 & Max & 12,79400 \\
\hline Min & $-0,580000$ & Min & $-0,702000$ \\
\hline Sum & 4,051000 & Sum & 14,28800 \\
\hline Std. Dev & 0,590857 & Std. Dev & 3,581412 \\
\hline Skew & 2,304475 & Skew & 2,973632 \\
\hline Kurt & 8,943273 & Kurt & 10,28603 \\
\hline Observation & 22 & Observation & 13 \\
\hline
\end{tabular}

The average of stock returns of Non Failed category has a higher nominal, that 1.099077 or 1.0, compared to Failed companies, 0.18. The highest value of stock returns are also still occupied by the Non Failed company, which amounted to 12.79 or $1279 \%$. Compared with stock returns Failed company ie 2.31 or $231 \%$. However, the company categorized Failed has the lowest value smaller than the companies categorized as Non-Failed which amounted to -0.70 or $-70 \%$, while the category Failed company has a minimum value of -0.58 or $-58 \%$. Overall stock returns Failed category is 4.05 or $405 \%$, and the company categorized Non Failed 14.29 or $1429 \%$.

\subsection{Mann Whitney Test}

Based on the Mann Whitney test, obtained the test results in Table 3.
Table 3: Mann Whitney Test

\begin{tabular}{|l|l|}
\hline Test Statistics $^{\mathbf{b}}$ & return \\
\hline Mann-Whitney U & 131.500 \\
\hline Wilcoxon W & 384.500 \\
\hline Z & -.394 \\
\hline Asymp. Sig. (2-tailed) & .694 \\
\hline Exact Sig. [2*(1-tailed Sig.)] & $.699^{\mathrm{a}}$ \\
\hline
\end{tabular}

a. Not corrected for ties.

b. Grouping Variable: kategori perusahaan

Based on the results of Mann Whitney test, a score P-value (Asymp. Sig 2-tailed) of 0.694, where the the P-value is greater than 0,025. According to the test criteria, when the $\mathrm{P}$ value (Asymp. Sig. 2-tailed) $>0.025$, then $\mathrm{Ho}$ is accepted. So there is no difference in the value of company stock returns in failed and non failed company.

\subsection{T-Test and Data Panel Regression}

The t-test was conducted to determine the relationship Oscore bankruptcy prediction on stock returns. The t-test is a procedure in which the sample results can be used to verify or disprove the null hypothesis (Ho). The results of the $t$ test performed with panel data regression model with Common Effect, panel data regression results described in the table

Tabel 4: T-Test

Dependent Variable: RETURN

Method: Panel Least Squares

Date: 11/25/15 Time: 18:26

Sample: 20102014

Periods included: 5

Cross-sections included: 7

Total panel (balanced) observations: 35

\begin{tabular}{|c|c|c|c|c|}
\hline Variable & Coefficient & Std. Error & t-Statistic & Prob. \\
\hline C & 0.687733 & 0.433538 & 1.586325 & 0.1222 \\
\hline SCORE & -0.035047 & 0.045411 & -0.771774 & 0.4457 \\
\hline
\end{tabular}

Based on panel data regression that has been done, the pvalue obtained from Ohlson Score of 0.4457 , where it's greater than $\alpha=0.05$. According to decision criteria, if the $\mathrm{p}$-value $>\alpha$, then Ho is accepted. So it can be concluded that there is no significant effect between the O-Score bankruptcy prediction towards return stock with a coefficient of -0.035047 Ohlson Score, which means the event of changes Ohlson Score rise by $1 \%$, then the return of the company's shares will be decreased by $0.035047 \%$. In other words, the higher the Ohlson Score, the lower the stock return. Coefficient of Determination aims to determine how far the model explains the dependent variable. The coefficient of determination is based on panel data regression that has been done is amounted to 0.017730 . From these figures we can conclude that the variable Ohlson Score, can explain the variable of $1.773 \%$ Stock Return. 


\section{International Journal of Science and Research (IJSR) \\ ISSN (Online): 2319-7064 \\ Index Copernicus Value (2013): 6.14 | Impact Factor (2014): 5.611}

\section{Conclusion}

Based on the analysis above it can be concluded that of all 35 calculation, which consists of seven companies, in which each company is divided into five periods (2010 2014), there are 22 calculations indicated Failed company, and 13 as Non Failed company. Based on descriptive analysis there are differences in the average and the number of stock returns failed and non-failed, but by Mann Whitney test, proved that there is no difference between the value of company stock returns failed and non failed.

From the results of this study can also be concluded that there is no significant influence between the O-Score bankruptcy prediction on stock returns, with a coefficient of Ohlson Score of -0.03547 and determination coefficient of .017730 , or $1.773 \%$, which means if there is an increase of Ohlson Score 1\%, then the return of the company's shares will be decreased by $0.035047 \%$. In other words, the higher the Ohlson Score, the lower the stock return.

\section{Future Scope}

For further research that will predict Ohlson Score, it is advisable to use real GNP in 2014 with the data that were not foreseen, as well as the views of the value of $\mathrm{R}$ Squared are very small, namely $1.773 \%$, further research can could input other variables that are expected to have high influence on the stock returns, mainly from external factors, such as the macroeconomic situation, the political situation, natural conditions, government regulations, or inside either outside nation issues.

\section{References}

[1] Central Bureau of Statistics (Badan Pusat Statistika). (2015). Berita Resmi Statistik Badan Pusat Statistik (No. 45/05/Th.XVIII). Jakarta,Indonesia:BPS

[2] Kontan (2013). BEI kembali coret satu emiten. Accesed on9 September 2015, fromhttp://investasi.kontan.co.id/news/bei-kembalicoret-satu-emiten

[3] Rodoni, A., Ali, H. (2010). Manajemen Keuangan. Bogor: Mitra Wacana Media

[4] Tandelilin, E. (2010). Portofolio dan Investasi Teori dan Aplikasi (Teori Pertama). Yogyakarta:Kansius

[5] Keown, A.,J., Martin, J.,D., Petty, J.,W., Scott., D.,J. (2005). Financial Management: Principles and Application. New York: Pearson Prentice Hall.

[6] Titman, S., Keown, A.,J., Martin, J.,D. (2011). Financial Management (Principles and Applications)7th ed. New York: Pearson Education Inc.

[7] Kamaludin. (2011). Manajemen Keuangan, Konsep Dasar dan Penerapanya. Bandung: CV.Mandar Maju

[8] Subramanyam,K.,R., Wild,J.,J.(2010). Analisis Laporan Keuangan 'Financial Statement Analysis'. Jakarta:Salemba Empat.

[9] Karamzadeh, M.,S. (2013). Application and Comparison of Altman and Ohlson Model to Predict Banruptcy of Companies. Research Journal of
Applied Science, Engineering and Technology, 5(6), 2007-2013.

[10] Ghozali, Imam. (2013). Aplikasi Analisis Multivariate dengan Program IBM SPSS 21 Update PLS Regresi (Edisi 7). Semarang: Badan Penerbit Universitas Diponegoro.

[11] Ohlson, J. (1980). Financial Ratio and Probabilistic Prediction Of Bankruptcy. Journal Of Accounting Research, 18(1), (Spring,1980).109-131. Publsihed by The Institute Of Professional Accounting, Graduate School Of Business, University of Chicago.

[12] Fahmi, I. (2012). Pengantar Manajemen Keuangan Teori dan Soal Jawab. Bandung: Alfabeta

[13] Herlianto, D. (2013). Manajemen Investasi Plus Jurus Mendeteksi Investasi. Yogyakarta: Gosyen.

[14] Sedarmayanti., Hidayat, S. (2011). Metodologi Penelitian. Bandung: CV. Mandar Maju.

[15] Rosadi, D. (2012). Ekonometrika \& Analisis Runtun Waktu Terapan dengan E Views. Yogyakarya: Andi

\section{Author Profile}

\begin{tabular}{|l|l|}
\hline & \\
\hline Name & \\
\hline Date Of Birth & Ayu Putri Wulandari \\
\hline Education & November, 21st 1994 \\
& SMP N 1 Kuta Utara \\
& SMK N 1 Denpasar \\
& Telkom University, Bandung \\
\hline Interest in & Financial Management. \\
\hline E-mail & Ayputriw@gmail.com \\
\hline Phone Number & +6287862420621 \\
\hline Occupation & Entrepreneur, Fresh graduate \\
\hline
\end{tabular}

\begin{tabular}{|l|l|}
\hline & \\
\hline Name & \\
\hline Date Of Birth & Dr. Norita, SE., M.Si., Ak., \\
CA & May, 22nd, 1961 \\
\hline Education & $\begin{array}{l}\text { Andalas University, Padang } \\
\text { (S1) }\end{array}$ \\
& $\begin{array}{l}\text { Padjadjaran University } \\
\text { Bandung (S2) University } \\
\text { Padjadjaran } \\
\text { Bandung (S3) }\end{array}$ \\
\hline E-mail & Ayputriw@gmail.com \\
\hline Phone Number & 081320454655 \\
\hline Occupation & Lecturer \\
\hline
\end{tabular}

JOURNAL OR PROCEEDINGS

\begin{tabular}{|c|c|c|c|}
\hline No & Year & Title & Journal \\
\hline 1 & 2012 & $\begin{array}{l}\text { Intellectual Capital: Concepts, } \\
\text { Models and Applications (Studies } \\
\text { in Banking Sector Listed in } \\
\text { Indonesia Stock Exchange Period } \\
\text { 2007-2010) }\end{array}$ & SNAB \\
\hline 2 & 2013 & $\begin{array}{lrr}\text { Comparative } & \text { Analysis } & \text { On } \\
\text { Corporate Condition Using } & \text { Z"- } \\
\text { Score Value } & \text { On } \\
\text { Telecommunication Sector and } \\
\text { "Gray" Zone Trend Determination } \\
\text { For The Year 2013 }\end{array}$ & ICOI \\
\hline
\end{tabular}




\begin{tabular}{|c|c|c|c|}
\hline 3 & 2013 & $\begin{array}{l}\text { Comparative Analysis on Stock } \\
\text { Intrinsic Value with Estimation of } \\
\text { Stock Value and Stock Market } \\
\text { Value For Decision Making "Buy, } \\
\text { Sell, or Hold" In } \\
\text { Telecommunication Sector at } \\
\text { Quarter I of } 2013\end{array}$ & ISCLO \\
\hline 4 & 2014 & $\begin{array}{l}\text { Analysis and Forecasting of } \\
\text { Bankruptcy Potential Using } \\
\text { Multiple Discriminant Analysis and } \\
\text { Double Moving Average on PT. } \\
\text { Bakrie Telecom, Tbk Year } 2013\end{array}$ & ICOI \\
\hline 5 & 2014 & 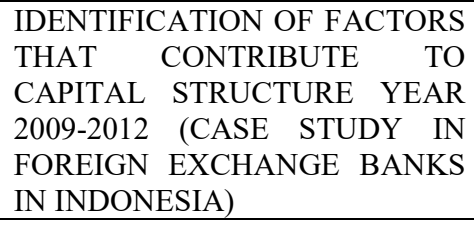 & GTAR \\
\hline 6 & 2015 & $\begin{array}{l}\text { An Analysis of Telecommunication } \\
\text { Vendor Company Bankruptcy } \\
\text { Potency Based on the Problematic } \\
\text { Financial Ratio with Altman, } \\
\text { Springate and Zmijewski Methods }\end{array}$ & ICOI \\
\hline
\end{tabular}

\begin{tabular}{|l|l|}
\hline & \\
\hline Name & Aldilla Iradianty, S.E, M.M \\
\hline Date Of Birth & June 30th,1987 \\
\hline Education & $\begin{array}{l}\text { Parahyangan University } \\
\text { Bandung, Indonesia } \\
\text { Magister Mangement, } \\
\text { majoring in Strategic } \\
\text { Management 2009 Padjajaran } \\
\text { 2005 - } \\
\text { University Bandung, Indonesia } \\
\text { Economic Faculty, majoring in } \\
\text { Finance Management }\end{array}$ \\
\hline Aldilla@ypt.or.id \\
\hline E-mail & 08212630 5599 \\
\hline Phone Number & Lecturer \\
\hline Occupation & \\
\hline
\end{tabular}

